\title{
ストリークカメラを用いた水中ストリーマの高時間分解解析
}

\section{Highly temporal analysis of underwater streamers with a streak camera}

\author{
○学 藤田 英理（東北大） \\ 正 小宮 敦樹（東北大） \\ 金澤 誠司（大分大） 正 大谷 清伸（東北大） \\ 金子 俊郎（東北大） 正 佐藤 岳彦（東北大）
}

\begin{abstract}
Hidemasa FUJITA, Tohoku University, 2-1-1 Katahira, Aoba-ku, Sendai 980-8577
Seiji KANAZAWA, Oita University, 700 Dannoharu, Oita 870-1192

Kiyonobu OHTANI, Tohoku University, 2-1-1 Katahira, Aoba-ku, Sendai 980-8577

Atsuki KOMIYA, Tohoku University, 2-1-1 Katahira, Aoba-ku, Sendai 980-8577

Toshiro KANEKO, Tohoku University, 6-6-05 Aoba, Aramaki, Aoba-ku, Sendai 980-8579

Takehiko SATO, Tohoku University, 2-1-1 Katahira, Aoba-ku, Sendai 980-8577
\end{abstract}

\begin{abstract}
The highly temporal streak imaging of an underwater discharge revealed that the primary streamer propagation was intermittent though the propagation had been considered continuous from our previous study. In addition, the intermittent luminescence pattern was synchronized with the pattern of discharge pulsed currents. The primary streamer in ultrapure water was generated by the application of a single-shot pulsed positive high voltage with a duration of $10 \mu \mathrm{s}$ to a needle-wire electrode system with the tip radius of $40 \mu \mathrm{m}$ and with the gap distance of $6 \mathrm{~mm}$.
\end{abstract}

Key Words: Underwater discharge, Streamer, Streak camera

\section{1. 緒言}

液中の針電極に高電圧を印加するとストリーマと呼ばれ るフィラメント状の発光現象が観測される. 液中ストリーマ は自発光だけでなく, シャドーグラフ法やシュリーレン法に より屈折率の変化としても可視化される(1).このとき観察さ れる影絵はストリーマ・チャネルと呼ばれる.

液中ストリーマの進展には紫外線, 衝撃波, 微細気泡, 才 ゾン, および化学活性種の生成を伴う(2). 特に水中ではヒド ロキシルラジカルやスーパーオキシドアニオンラジカルの ような酸化力の高いラジカル種が形成されるため, 水質浄化 や医療分野への応用が期待されている(3).

水中正ストリーマは形状や進展速度, 放電電流波形から 1 次ストリーマと 2 次ストリーマに分類されている(4)-(8). 1 次 ストリーマは半球ブラシ状に $2-3 \mathrm{~km} / \mathrm{s}$ で進展し, 電流波形上 には繰り返しパルス電流が観測される(4)(7). 他方, 2 次スト リーマは樹枝形状を有し, 進展速度は 20-30 $\mathrm{km} / \mathrm{s}$ に達する (4)-(6),(8). 2 次ストリーマの進展時には電流波形上に直流成分 が現れ，低電気伝導率の水中では断続的なスパイク電流が続 ${ }^{(5)(6)(8)}$.このスパイク電流は 2 次ストリーマの進展後に形 成されたチャネル内での気相中放電を表している(5)(6). 1 次 ストリーマは 2 次ストリーマに比べて進展長が短く, 発光も 微弱なため観測が難しい。そのため，1 次ストリーマの自発 光はイメージインテンシファイアと高感度カメラを組み合 わせた単一写真として可視化されているものの ${ }^{(7)}$, 連続写真 としては観察されていない. 顕微鏡レンズと超高速度カメラ を組み合わせることで1次ストリーマの進展を連続的に可視

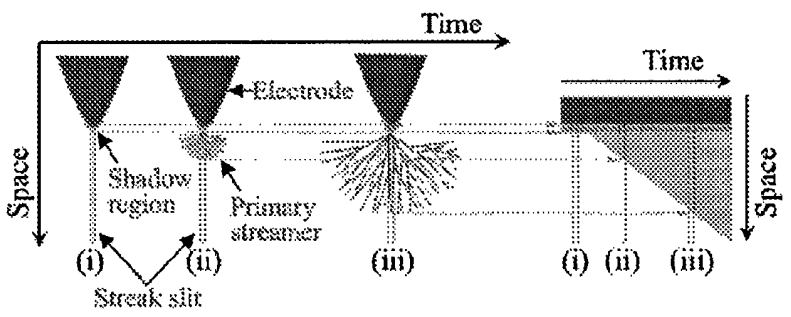

(a) 20 images

(b) Streak image

Fig. 1 Schematic of the visualization results of primary streamer propagation by means of (a) an ultra high-speed camera and (b) a streak camera.
化することができる(7). しかしこの場合，強力な背景光を用 いてストリーマ・チャネルを可視化するため, パルス状の電 流波形に関わらず，その進展は連続的に観測される.このよ うに, 水中ストリーマの詳細な進展機構は未だ十分解明され ていない.

そこで本研究では, 高感度で高時間分解能のストリークカ メラを用いて1次ストリーマの自発光を連続的に可視化した. また，ストリーク写真と電流波形を同期させることで，1 次 ストリーマの進展とそれを特徴付ける繰り返しパルス電流 の関連性を検証した.

\section{2. 実験}

2-1 放電装置と放電条件 放電セルに石英ガラスセルを用い, 内部に電極間距離 $6 \mathrm{~mm}$ の針-ワイヤ電極を固定した. 両電極 ともに直径 $0.5 \mathrm{~mm}$ の白金線で作成し，放電部を除き絶縁管 で被覆している. 針電極の先端は約 $40 \mu \mathrm{m}$ の曲率半径に加工 した. セラミックコンデンサを介して $10 \mu \mathrm{s}$ の単一正パルス 電圧を針電極に印加する．電圧の立ち上り時間は約 $200 \mathrm{~ns}$ である.また, ワイヤ電極は接地している. 水は空気曝露後 に電気伝導率が約 $0.8 \mu \mathrm{S} / \mathrm{cm}$ に上昇した超純水を用いた。

2-2 計測方法 可視化にはストリークカメラ（浜松ホトニク ス，C10910）を使用した。本実験で用いた掃引ユニットの最 大時間分解能は $20 \mathrm{ps}$ である。撮影には顕微鏡レンズを使用 し, 背景光にフラッシュランプを用いた. 電圧ならびに電流 波形は高電圧プローブおよび電流プローブを用いて計測し， ストリークカメラのゲート信号と共にオシロスコープ上で モニタリングした.

2-3 ストリーク写真 ストリーク写真では, 空間情報が 1 次 元に限られるが，現象の連続的な時間変化の観察が可能とな る. 図 1 (a)に 1 次ストリーマの進展を超高速度カメラで撮影 したときに得られる画像のうち, 3 フレーム分を示している. 電極先端に描いた長方形はストリークカメラのスリットを 表し, 図 1 (b)に示すように, ストリークカメラで得られる空 間情報はこのスリット内に限られる，しかし図 1 (b)では，超 高速度カメラでは得られない1次ストリーマの連続的な時間 変化を可視化することができる．

\section{3. 結果および考察}

図 2 に背景光を入れて撮影した 1 次ストリーマ進展のスト 


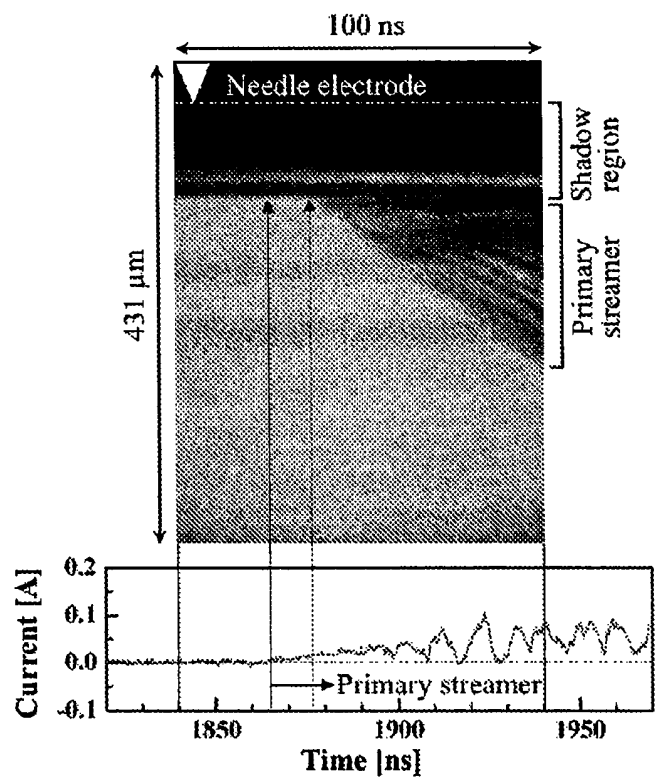

Fig. 2 A streak image with the backlight and the synchronized

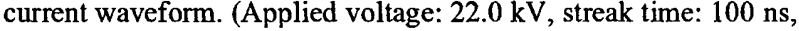
space: $431 \mu \mathrm{m}$ )

リーク写真およびその電流波形を示す. 写真中の の位置を示し，針電極より下方の影領域は，電圧の立ち上が りから1次ストリーマ進展前までの遅れ時間に形成された気 泡領域を表す(5)，1 次ストリーマの進展は三角形の影として 電圧印加後 $1877 \mathrm{~ns}$ から観察される. 背景光を入れて観察し た場合，ストリーマの進展は連続的に観察され，三角形の傾 きから見積もられる平均進展速度は $2.4 \mathrm{~km} / \mathrm{s}$ になる。こうし た観測結果は，超高速度カメラを用いたシャドーグラフ法の 可視化結果とよく一致する ${ }^{(7)} .1$ 次ストリーマの進展を示唆 する電流波形の変動は 1 次ストリーマ進展開始前の $1865 \mathrm{~ns}$ からみられる.ストリークカメラのスリットは図 1 (a)の模式 図に示すように針電極の先端に合わせているが，1 次スト リーマの進展は必ずしも針電極先端から始まるわけではな い. 図 2 ではスリットの外側から進展を開始して, $1877 \mathrm{~ns}$ 以降にスリット内部まで進展領域が広がったものと解釈で きる.

図 3 に示すように, 背景光を消し，カメラの感度を最大に して 1 次ストリーマの進展を撮影すると, 断続的な発光が観 測された。ささらに時空間分解能を約 2 倍に向上させたスト リーク写真を図 4 に示す. 図 4 では 1 次ストリーマの進展開 始から $130 \mathrm{~ns}$ 後にカメラゲートを開いている.このときスト リーマの断続的な発光のタイミングとパルス電流はおおよ そ一致していた.

パルス電流と同期した断続的な進展は，2 次ストリーマ進 展後にみられるスパイク電流と同期したストリーマ・チャネ ル内での気相中放電を類推させる.すなわち 1 次ストリーマ の進展は，チャネル先端の電界集中による水中電離に始まり， 多量の電子が気相チャネルを介して電極先端に向かって駆 動され, 気相中放電に至る機構が示唆される. ストリ一マ・ チャネル先端はガス化することでわずかに伸長し，チャネル 先端で再び電界集中が起こるまで休止期間ができる，この繰 り返しが断続的な進展を引き起こすと推測される。

\section{4. 結言}

ストリークカメラを用いて水中 1 次ストリーマの進展を可 視化した. 背景光を用いた場合, これまで超高速度カメラで 観測したように1次ストリーマの進展は連続的に観測される. しかし，背景光を消して自発光を観測すると 1 次ストリーマ

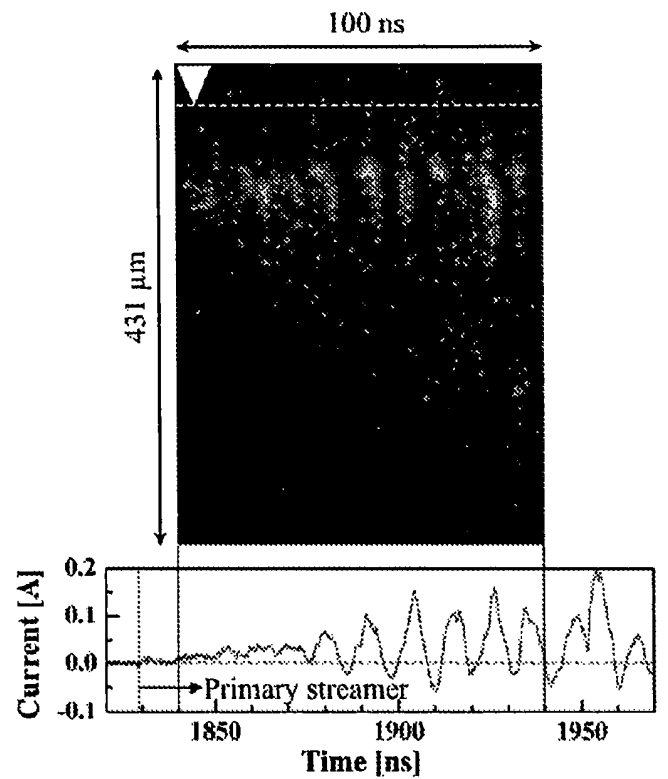

Fig. 3 A streak image without the backlight and the synchronized current waveform. (Applied voltage: $22.0 \mathrm{kV}$, streak time: $100 \mathrm{~ns}$, space: $431 \mu \mathrm{m}$ )

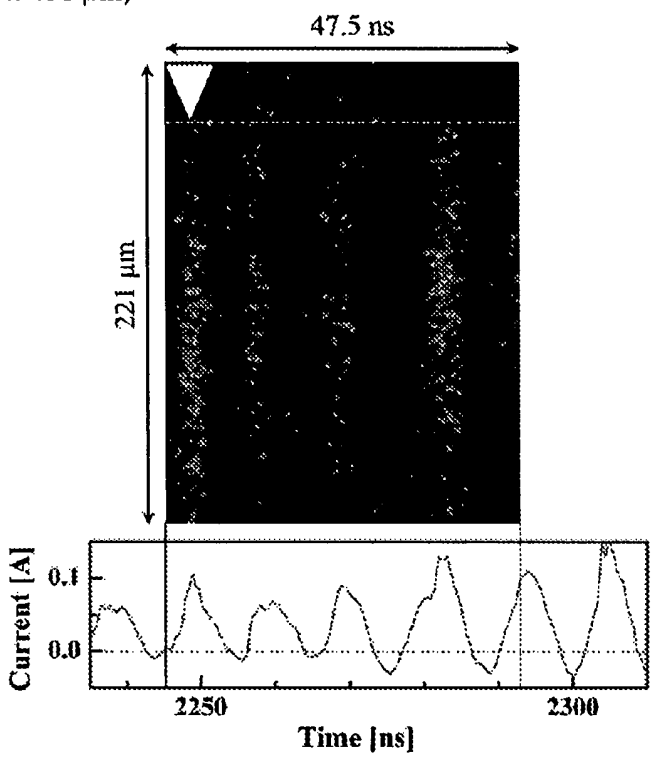

Fig. 4 Streak image with backlight turned off and the synchronized current waveform. (Applied voltage: $22.0 \mathrm{kV}$, streak time: $47.5 \mathrm{~ns}$, space: $221 \mu \mathrm{m}$ )

は断続的に進展していた．また，発光のタイミングは電流波 形のパルス成分に一致していた。

本研究は, 科研費扝よび東北大流体研公募共同研究の支援 を得た，実験遂行において、東北大流体研中嶋智樹技術専門 職員の支援を得た。ここに謝意を表す。

引用文献

(1) 吉野他, 液体エレクトロニクス, (1996), コロナ社.

(2) H. Akiyama, IEEE Trans. Electr. Insul., 7 (2000), 646-653.

(3) P. Bruggeman and C. Leys, J. Phys. D: Appl. Phys., 42 (2009), 053001

(4) W. An et al., J. Appl. Phys., 101 (2007), 053302.

(5) P. H. Ceccato et al., in Proc. IEEE Pulsed Power Conf., (2010), 866-871.

(6) P. H. Ceccato et al., D: Appl. Phys., 43 (2010), 175202.

(7) H. Fujita et al., J. Appl. Phys., 113 (2013), 113304.

(8) H. Fujita et al., EPL, 105 (2014), 15003. 